\title{
The determinants and interrelationship of carbon emissions and economic growth in African economies: Fresh insights from static and dynamic models
}

\author{
Solomon Nathaniel ${ }^{1} \odot$ | Suborna Barua ${ }^{2}$ | Hamid Hussain $^{3} \odot$ | Ngozi Adeleye $^{4}$
}

${ }^{1}$ Department of Economics, University of Lagos, Akoka, Nigeria

${ }^{2}$ Department of International Business, University of Dhaka, Dhaka, Bangladesh

${ }^{3}$ Department of Economics and Finance, Institute of Business Administration, Karachi, Pakistan

${ }^{4}$ Department of Economics and Development Studies, Covenant University, Ota, Ogun State, Nigeria

\section{Correspondence}

Solomon Nathaniel, Department of Economics, University of Lagos, Akoka, Nigeria.

Email: nathaniel_solomon21@yahoo.com
This study explores the interrelationship between $\mathrm{CO}_{2}$ emissions and economic growth in selected Africa economies from 1990 to 2014 providing evidence from both static and dynamic models. Results show that increases in energy use have a significant and positive effect on economic growth; which goes to show that growth in Africa is actually energy dependent. Further findings suggest that $\mathrm{CO}_{2}$ emissions have no significant contemporaneous effect, however, a significant and negative effect at a one-period lag on economic growth. The significance of the impacts is consistently confirmed by both the static and dynamic estimations. Also, trade adds to economic growth and also contributes to environmental deterioration in Africa. There is a dire need for Africa to adjust its energy portfolio by shifting to clean energy sources which will enhance sustainable economic growth without deteriorating the environment.

\section{1 | INTRODUCTION}

According to the World Bank (2017), at least, about $14 \%$ of the people living in the world live in SSA, and Africa is the second most populated continent behind Asia. For the past few decades, an increase in growth/development and population witnessed in the world has been unprecedented. Urbanization and industrialization have been the key drivers of this phenomenon increase (Dong, Jiang, Sun, \& Dong, 2019; Nathaniel et al., 2019). This increase is however at a cost. It results in more energy (nonrenewable) demand. This explains why global energy demand has increased to $13,105.0$ (Mtoe) in 2015 from 6,642.3 in 1980 (BP, 2017). On the flip side, the global $\mathrm{CO}_{2}$ concentration in the atmosphere also increased to $404.7 \mathrm{ppm}$ in 2016 (ESRL, 2017). In the same year, global temperature increased by $1.26^{\circ} \mathrm{C}$ (Hansen et al., 2017). The concomitant upward surge in energy use (EUS) and urbanization has done no good to the environment especially in terms of $\mathrm{CO}_{2}$ emissions (Dong, Sun, Li, \& Liao, 2018; Shen et al., 2018; Shuai, Chen, Wu, Zhang, \& Tan, 2019; Shuai, Shen, Jiao, Wu, \& Tan, 2017). Between 2000 and 2017, the growth in urban population (in Africa) has increased from $30.8 \%$ to $38.8 \%$. Also, the GDP growth rate of the region average of 2.2\% between 2015 and 2017 (Wang \& Dong, 2019).
The urgent need to make the environment habitable for humanity caused 196 countries to not only support but also join the United Nations Framework Convention on Climate Change (UNFCCC) in 2015. Countries in support of the UNFCCC have been holding a series of meeting since 1995 on the steps needed to abate global warming. One notable outcome of their meetings was the birth of the Kyoto Protocol in 1997. The protocol initiated binding obligations, especially for developed countries, to reduce their emissions. Good as it seems, this agreement was never a global one as the special focus was on the European Union and other few developed countries leaving out the top emitters like, the United States, India, and Canada who failed to ratify the agreement. Subsequently, parties of the UNFCCC, consisting more than 194 countries, adopted the Paris Agreement on December 2015 with the willingness to reduce GHGs well below $2^{\circ} \mathrm{C}$ by 2,100 . This is, however, becoming doubtful with the passing of each day holding to the withdrawal of the United States (on June 1, 2017) from the agreement. The United States claimed that the agreement empowers other nations at the expense of the United States. Whichever way the coin turns out, the Paris Agreement was a landmark achievement, and adhering strictly to it, is germane for environmental sustainability. With this achievement, global 
cooperation, with regard to environmental protection, witnessed new dawn (Bloomberg \& Pope, 2017; Zhang, Chao, Zheng, \& Huang, 2017).

Securing the biodiversity is important for human survival, also for sustainable growth and development. As a result, for over two decades now, many studies on the nexus between selected macroeconomic variables and $\mathrm{CO}_{2}$ emissions have been unprecedented (see, for instance, Ozturk \& Acaravci, 2010; Ozatac, Gokmenoglu, \& Taspinar, 2017; Destek \& Sarkodie, 2019; Jamel \& Derbali, 2016; Saboori, Sulaiman, \& Mohd, 2012; Ozatac et al., 2017; Kahia, Aïssa, \& Lanouar, 2017; Green \& Stern, 2017). While some specifically explored growth and $\mathrm{CO}_{2}$ emissions nexus in Africa (Aboagye \& Kwakwa, 2014; Al-Mulali \& Sab, 2012; Asongu, El Montasser, \& Toumi, 2016; Esso \& Keho, 2016; Gao \& Zhang, 2014; Hamilton \& Kelly, 2017; Kais \& Ben Mbarek, 2017; Saidi \& Hammami, 2015). Global warming caused majorly by carbon emissions (Bong et al., 2017; Lv \& Xu, 2019) have made life seemingly difficult for humanity. It causes climate change. This change is a global problem. It is not exclusive to developed countries alone (Ito, 2017). The horrendous effects of climate change have been a serious challenge facing the world. If $\mathrm{CO}_{2}$ emissions must be mitigated, a clear knowledge of its major drivers are sacrosanct (Dong et al., 2019; Sarkodie \& Strezov, 2018; Sarkodie \& Strezov, 2019).

Against this backdrop, numerous research studies have been dedicated to the determinants of emissions both in a single country case (Brizga, Feng, \& Hubacek, 2013; Cansino, Román, \& Ordonez, 2016; Chin, Puah, Teo, \& Joseph, 2018; Mrabet \& Alsamara, 2017; Raggad, 2018) and for a group of countries (Balogh \& Jámbor, 2017; Dogan \& Seker, 2016; Iwata, Okada, \& Samreth, 2012; Li \& Lin, 2015; Lin, Wang, Marinova, Zhao, \& Hong, 2017; Moutinho, Moreira, \& Silva, 2015; Sharma, 2011; Shuai et al., 2017; Yeh \& Liao, 2017). China and the United States are the two biggest emitters of $\mathrm{CO}_{2}$ (Liu \& Xiao, 2018). Although developing countries (especially countries in Africa) are not among the highest emitters of $\mathrm{CO}_{2}$ yet they are not spared from its negative consequences. These consequences transcend all facets of human life. The continuous usage of the nonrenewable energy sources in Africa, which increased to 69\% in 2017 (Dong et al., 2019) has the potential to subject the region to more environmental calamity if the 2015 Climate Change Vulnerability Index report is anything to go by. According to this report, Eritrea, Central African Republic, Ethiopia, Chad, Nigeria, South Sudan, and Sierra-Leone are among the top 10 countries most vulnerable to climate change negativity (Sarkodie, 2018). This was one of the motivating factors for this study. Whether the quality of the environment has also truncated growth in the region, was another motivation for the study.

However, unlike previous studies that either concentrated on $\mathrm{CO}_{2}$ emissions determinants or on the determinants of growth in Africa, we simultaneously estimated both by providing evidence from both static (Feasible Generalized Least Square [FGLS] and PraisWinsten Panel Corrected Standard Errors [PCSEs]) and dynamic (System Generalized Methods of Moments [Sys-GMM]) estimations. Our study considers growth as a determinant of $\mathrm{CO}_{2}$ emission and vice versa. Also, the study used the second-generation estimation techniques robust for cross-sectional dependence among the countries considered, a phenomenon that was hardly considered in previous studies.

The study is outlined as follows: Section 2 shows a review of the literature. Section 3 presents the data source and methodology. The results are discussed in Section 4. Section 5 concludes with relevant policy direction.

\section{2 | LITERATURE REVIEW}

In this section, the literature is divided into two strands: those that emphasized the determinants of $\mathrm{CO}_{2}$ emissions and those that concentrate on factors that drive growth.

\subsection{Determinants of $\mathrm{CO}_{2}$ emissions}

The reduction in the quality of the environment has been a subject of intense debate for both economists and environmentalists. As such, the literature is awash with studies directed to unveiling the factors that could be responsible for the malady. However, various factors have been unveiled as drivers of $\mathrm{CO}_{2}$ emissions both for country-specific and regional studies. For instance, relying on data spanning 2005-2016, Ma et al. (2019) provided evidence of a well-knitted association between $\mathrm{CO}_{2}$ emissions and EUS. Similarly for 10 industrialized countries, with data spanning 1991-2013, Ghazali and Ali (2019) discovered that population drives $\mathrm{CO}_{2}$ emissions. A feedback causality was also discovered between population and growth, and between $\mathrm{CO}_{2}$ emissions and energy intensity. By using a ridge regression on regional data from China, Wang, Wang, Li, Fang, and Feng (2019) were able to affirm that urbanization, population, and industrialization, which are mainly socioeconomic factors, add to $\mathrm{CO}_{2}$ emissions. Sarkodie et al. (2019) through a dynamic ARDL simulation model discovered that EUS increases emission in Australia, and 13\% emission rate can be abated with an increase in biomass consumption. Azizalrahman (2019) explored the contribution of the urban sector to emissions relying on the ARDL technique. Urbanization and energy consumption were the major factors that deteriorate the environment. Saidi and Mbarek (2017) pointed out in their study of 19 emerging economies that urbanization and trade stimulate $\mathrm{CO}_{2}$ emissions. They, however, noted that financial development (FDM) was healthy for the environment. They concluded that aggressive financial reform is germane for sustainable growth. Studies on FDM and $\mathrm{CO}_{2}$ emissions nexus have remained largely inconclusive (see Atici, 2009; Dogan, Seker, \& Bulbul, 2017; Ertugrul, Cetin, Seker, \& Dogan, 2016; Hossain, 2011; Lau, Choong, \& Eng, 2014; Le, Chang, \& Park, 2016; Nasir \& Rehman, 2011; Rafiq, Salim, \& Nielsen, 2016; Sbia, Shahbaz, \& Hamdi, 2014; Sebri \& Ben-Salha, 2014; Shahbaz, Nasreen, Ahmed, \& Hammoudeh, 2017). Sarkodie and Strezov (2019) discovered that FDI degrades the environment in their study of five developing countries from 1982 to 2016. Apart from FDI, an increase in 
emissions was attributed to EUS in all the countries except Indonesia. This is similar to what Zhou, Fu, Kong, and Wu (2018) reported for China. On the flipside, Khan, Saleem, and Fatima (2018) discovered the exact opposite for the case of India, Bangladesh, and Pakistan after utilizing the FMOLS for data spanning 1980-2014. They discovered that FDI is environmentally friendly. Also, Agboola and Bekun (2019) reported that FDI is not particularly harmful to the environment in Nigeria. The contradictory findings of Sarkodie and Strezov (2019) and Khan et al. (2018) could be as a result of the differences in data, country and estimation techniques. For studies on FDI and $\mathrm{CO}_{2}$ interaction (see Omri, Nguyen, \& Rault, 2014; Shahzad, Kumar, Zakaria, \& Hurr, 2017; Solarin, Al-Mulali, Musah, \& Ozturk, 2017; Zakarya, Mostefa, Abbes, \& Seghir, 2015; Zhang \& Zhou, 2016). Balcilar, Bekun, and Uzuner (2019), Bukhari and Waseem (2017) and Mirza and Kanwal (2017) used a similar technique (ARDL) and arrived at a similar conclusion for Pakistan. They both affirmed that EUS drives $\mathrm{CO}_{2}$ emissions. Also, energy consumption was accorded the main driver of emissions. Salahuddin, Alam, Ozturk, and Sohag (2018) applied the ARDL technique on data spanning 1980-2013 and used the DOLS to check for robustness. They reported that FDI, EUS, and growth stimulate $\mathrm{CO}_{2}$ emission and also Granger cause $\mathrm{CO}_{2}$ emissions. Bekun, Alola, and Sarkodie (2019) discovered that fossil fuels consumption contributes to environmental deterioration in 16-EU countries, while renewable energy consumption adds to environmental quality.

\section{2 | Determinants of economic growth}

The growth of an economy indirectly affects working conditions, the sailing of enterprises and decision-making. Maintaining steady growth enhances enterprises development even when enterprises do not have any direct control of factors that drive it ( $\mathrm{He} \& \mathrm{Xu}, 2019$ ). Providing answers to questions relating to the factors that add to growth dates back to the seminar works of Barro (1991) and Mankiw, Romer, and Weil (1992). However, the literature still remains largely inconclusive. The earlier set of authors support innovation, human capital, population, income, and investments as key drivers of growth (Barro \& Lee, 1993; Birdsall \& Rhee, 1993; De Long \& Summers, 1991; Galindo Martín, Ribeiro, \& Mendez Picazo, 2012; Maria, 2010; Weng, Song, \& Sheng, 2012; Ye \& Sun, 2010) and complemented by recent studies (like Aydin, Alrajhi, \& Jouini, 2018; Erdil Şahin, 2015; Esmail \& Hemdan, 2018; Kacprzyk \& Doryń, 2017; Lee, 2018; Tsaurai, 2017; Ustabaş \& Ersin, 2016; Zhao, 2016) and these studies relied on the Solow model as a baseline for variables selection. Bruce and Turnovsky (2013a) have attributed the growth in the economy to demographic factors like fertility, life expectancy, age among others (see Bruce \& Turnovsky, 2013b; Yew \& Zhang, 2013; Mierau \& Turnovsky, 2014; Bloom, Canning, \& Sevilla, 2004; Well, 2007). Another strand of studies has created a link between growth and macroeconomic variables, and has also identified different directions of causality between both (Alfaro, Chanda, Kalemli-Ozcan, \& Sayek, 2004; Ivanović \& Stanišić, 2017; Prašnikar, Redek, \&
Drenkovska, 2017; Yülek, 2017). Recently, institutional qualities have also been assigned a chief role in determining economic growth (Acemoglu, Johnson, \& Robinson, 2005; Barro, 2003; Bildirici, 2008; Butkiewicz \& Yanikkaya, 2006; Chong \& Calderon, 2000; Fraj, Hamdaoui, \& Maktouf, 2018; Gwartney, Holcombe, \& Lawson, 2004; Henderson, Papageorgiou, \& Parmeter, 2011; Ji, Magnus, \& Wang, 2014; Klein, 2005; Law, Azman-Saini, \& Ibrahim, 2013; Sobel, 2008; Valeriani \& Peluso, 2011). A large number of studies acknowledged energy (both nonrenewable and renewable) as determinants of growth (Alam, Ahmed, \& Begum, 2017; Arifin \& Syahruddin, 2011; Bildirici, 2016; Bildirici \& Özaksoy, 2018; Carmona, Feria, Golpe, \& Iglesias, 2017; Cetin, 2016; Destek, 2017; Koengkan, 2018; Liu, Zhang, \& Bae, 2018; Menegaki \& Ozturk, 2016; Ohlan, 2016; Zafar, Shahbaz, Hou, \& Sinha, 2019).

Apart from the studies above, Table 1 presents the list of some more studies on the determinants of economic growth.

\section{3 | METHODOLOGY}

This section outlines the variable specification, the econometric models, the estimation methods, and the data to be used in this research.

\section{1 | Variables}

The study uses panel data for exploring the dynamic relationship and the determinants of economic growth and carbon emissions in African economies. To furnish the purpose, the following variables are considered in this research based on the available empirical literature. Detailed definitions of all the variables in are Table A1. All variables except for FDM are transformed in natural logarithm to remove large and extreme value bias associated with the data used for the variables. Table 2, shows the list of variables considered and their proxies.

\section{2 $\quad$ Econometric model}

Based on the variables selected, we begin with the following specifications that can estimate the interrelationship and the determinants of GDPPC and $\mathrm{CO}_{2}$ emission:

$$
\begin{gathered}
\mathrm{GDPPC}_{\mathrm{it}}=\alpha+\sum_{j=1}^{p} \beta_{j} X_{\mathrm{it}}+\sum_{j=1}^{m} \delta_{j} \mathrm{CFE}_{\mathrm{dum} j}+\sum_{j=1}^{n} \theta_{j} Y_{j}+\varepsilon_{\mathrm{it}} \\
\mathrm{CO}_{\text {it }}=\alpha+\sum_{j=1}^{p} \beta_{j} X_{\mathrm{it}}+\sum_{j=1}^{m} \delta_{j} \mathrm{CFE}_{\mathrm{dum} j}+\sum_{j=1}^{n} \theta_{j} Y_{j}+\varepsilon_{\mathrm{it}}
\end{gathered}
$$

where $\alpha$ denotes constant, $i$ for country, $t$ for year, $X_{i t}$ stands for the explanatory variables, $\beta_{j}$ is coefficient of the individual independent variable, $\mathrm{CFE}_{\mathrm{dum}}$ is country fixed-effect dummy, $\delta_{\mathrm{j}}$ is coefficient for 
TABLE 1 Summary of studies on the determinants of growth

\begin{tabular}{|c|c|c|c|c|}
\hline Author & Country(s)/region & Duration & Method & Finding(s) \\
\hline Radu (2015) & $\begin{array}{l}\text { Central and Eastern } \\
\text { European countries }\end{array}$ & $1990-2010$ & $\begin{array}{l}\text { Multivariate } \\
\text { regression }\end{array}$ & $\begin{array}{l}\text { Political indicators do not have a direct } \\
\text { influence on growth }\end{array}$ \\
\hline Lee and Hong (2012) & 12 Asian economies & $1981-2007$ & $\begin{array}{l}\text { Growth accounting } \\
\text { framework }\end{array}$ & $\begin{array}{l}\text { Capital accumulation contributes more to } \\
\text { growth than other factors }\end{array}$ \\
\hline $\begin{array}{l}\text { Leon-Gonzalez and } \\
\text { Vinayagathasan (2015) }\end{array}$ & 27 Asia countries & 1980-2009 & BMA & $\begin{array}{l}\text { When inflation is greater than } 5.43 \% \text {, it } \\
\text { impedes growth }\end{array}$ \\
\hline $\begin{array}{l}\text { Burney, Mohaddes, } \\
\text { Alawadhi, and Al- } \\
\text { Musallam (2018) }\end{array}$ & Kuwait & $\begin{array}{l}\text { 1979Q2- } \\
\text { 2013Q1 }\end{array}$ & VAR & $\begin{array}{l}\text { Oil revenue and technological progress } \\
\text { drive growth }\end{array}$ \\
\hline $\begin{array}{l}\text { Ihnatov and } \\
\text { Sprincean (2015) }\end{array}$ & 16 CEE countries & 1990-2012 & Sys-GMM & $\begin{array}{l}\text { Intermediate and floating exchange rate } \\
\text { significantly affect growth. }\end{array}$ \\
\hline Smaoui and Nechi (2017) & Sukuk market & $2005-2015$ & Sys-GMM & $\begin{array}{l}\text { Development in Sukuk market } \\
\text { encourages growth }\end{array}$ \\
\hline $\begin{array}{l}\text { Shahbaz, Zakaria, Shahzad, } \\
\text { and Mahalik (2018) }\end{array}$ & 10 countries & $\begin{array}{l}\text { 1960Q1- } \\
\text { 2015Q4 }\end{array}$ & $\begin{array}{l}\text { Quantile-on-Quantile } \\
\text { regression }\end{array}$ & $\begin{array}{l}\text { The association between growth and } \\
\text { EUS was positive }\end{array}$ \\
\hline Gozgor, Lau, and Lu (2018) & 29 OECD & $1990-2013$ & $\begin{array}{l}\text { Panel quartile } \\
\text { regression, } A R D L\end{array}$ & RE and NRE promote growth \\
\hline Aydin and Esen (2018) & $\begin{array}{l}12 \text { Commonwealth } \\
\text { countries }\end{array}$ & 1991-2013 & $\begin{array}{l}\text { Panel threshold } \\
\text { analysis }\end{array}$ & $\begin{array}{l}\text { Growth will be retarded if energy } \\
\text { intensity exceeds } 0.44 \% \text { threshold }\end{array}$ \\
\hline
\end{tabular}

Note: Source: Authors' computations.

Abbreviations: ARDL, autoregressive distributed lag; BMA, Bayesian model averaging; $\mathrm{CO}_{2}$, carbon emissions; EU, energy use; EX, export; GFCC, gross fixed capital consumption; GMM, generalized method of moment; IM, import; NRE, nonrenewable energy; RE, renewable energy; VAR, vector autoregressive; VECM, vector error correction model.

country fixed-effect dummy, $Y$ captures time fixed effect by year dummy, and $\theta_{j}$ is coefficient for time fixed-effect dummy. The country fixed effects control for the heterogonous unobserved factors across the countries and the time (year) fixed effects $\left(Y_{j}\right)$ to capture the timetrend effects over the years considered. Replacing the explanatory variables with necessary logarithmic forms, we reformulate the following models for estimations:

$$
\begin{aligned}
\operatorname{lnGDPPC}_{\text {it }}= & \alpha+\beta_{1} \mathrm{GCF}_{\mathrm{it}}+\beta_{2} \ln T_{\text {it }}+\beta_{3} \operatorname{InEUS} S_{\text {it }}+\beta_{4} \ln C O 2_{i t} \\
& +\beta_{5} \mathrm{FDM}_{\mathrm{it}}+\sum_{j=1}^{m} \delta_{j} \mathrm{CFE}_{\mathrm{dum} j}+\sum_{j=1}^{n} \theta_{j} Y_{j}+\varepsilon_{i t}
\end{aligned}
$$

$$
\begin{aligned}
\operatorname{InCO}_{2 \mathrm{it}}= & \alpha+\beta_{1} \operatorname{InGDPPC}_{\mathrm{it}}+\beta_{2} \mathrm{GCF}_{\mathrm{it}}+\beta_{3} \ln \mathrm{T}_{\mathrm{it}}+\beta_{4} \ln \mathrm{EUS}_{\mathrm{it}} \\
& +\beta_{5} \mathrm{FDM}_{\mathrm{it}}+\sum_{j=1}^{m} \delta_{j} \mathrm{CFE}_{\mathrm{dum} j}+\sum_{j=1}^{n} \theta_{j} Y_{j}+\varepsilon_{i t}
\end{aligned}
$$

Equations (3) and (4) are estimated in this research using both the static and dynamic panel data estimators. However, Equations (3) and (4) could be misspecified in the current form and their straight estimations in this form could lead to inconsistent estimates, as many of the variables could be exposed to endogeneity bias. To deal with endogeneity, we introduce lags in the two equations for the necessary variables chosen based on the empirical literature. In Equation (1), 
GDPPC could be affected by its own lags and the lags of particularly gross capital formation (GCF), EUS, $\mathrm{FDM}$, and $\mathrm{CO}_{2}$; assuming that the effects of these four variables could take some time to reflect in the national economic performance, that is, the values of GDP. Hence, we consider a one-period (1 year) lag of GDPPC, GCF, EUS, FDM, and $\mathrm{CO}_{2}$ in addition to their level data in Equation (3) for final estimation. In a similar approach, in Equation (3), $\mathrm{CO}_{2}$ emission could be affected by its own lags and the lags of the explanatory variables, particularly of GDPPC, GCF, T, and EUS; assuming that a time lag is necessary to reflect the effects of these variables on $\mathrm{CO} 2$ emission. Therefore, to correct for endogeneity bias, we consider a one-period (1 year) lag of $\mathrm{CO}_{2}$, GDPPC, GCF, T, and EUS in Equation (4) for final estimation. Considering the lags, Equation (3) and (4) can be rewritten as follows:

TAB LE 2 List of variables selected

\begin{tabular}{|c|c|}
\hline Variable & Rationale/proxy for \\
\hline $\begin{array}{l}\text { GDP per capita (GDPPC) } \\
\text { in } 2010 \text { constant US\$ }\end{array}$ & To measure economic growth \\
\hline $\begin{array}{l}\mathrm{CO}_{2} \text { emission in kilo ton } \\
(\mathrm{kt})\end{array}$ & $\begin{array}{l}\text { Carbon emission, pollution, and } \\
\text { environmental performance of at the } \\
\text { national level }\end{array}$ \\
\hline GCF as $\%$ of GDP & $\begin{array}{l}\text { The level of aggregate investments in } \\
\text { the economy }\end{array}$ \\
\hline Trade (\% of GDP) & $\begin{array}{l}\text { The sum of import and export measured } \\
\text { as a share of GDP }\end{array}$ \\
\hline $\begin{array}{l}\text { EUS ( } \mathrm{kg} \text { of oil equivalent } \\
\text { per capita) (EUS) }\end{array}$ & $\begin{array}{l}\text { The level of energy consumption in the } \\
\text { economy }\end{array}$ \\
\hline FDM as $\%$ of GDP & $\begin{array}{l}\text { The degree of development, that is, } \\
\text { access and depth, of the domestic } \\
\text { financial sector }\end{array}$ \\
\hline
\end{tabular}

Note: Source: Author compiled.

Abbreviations: EUS, energy use; FDM, financial development; GCF, gross capital formation.

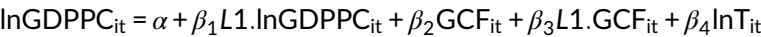

$$
\begin{aligned}
& +\beta_{5} \operatorname{InEUS} \mathrm{S}_{\mathrm{it}}+\beta_{6} \mathrm{L1}_{1 . \operatorname{InEUS}}+\beta_{7} \operatorname{lnCO} 2_{\mathrm{it}}+\beta_{8} L 1 . \operatorname{lnCO} 2_{\mathrm{it}} \\
& +\beta_{9} \mathrm{FDM}_{\mathrm{it}}+\beta_{10} \mathrm{L1}_{\mathrm{FDM}}+\sum_{j=1}^{m} \delta_{\mathrm{j}} \mathrm{CFE}_{\mathrm{dum} j}+\sum_{j=1}^{n} \theta_{j} Y_{j}+\varepsilon_{i t} \\
& \operatorname{lnCO} 2_{\text {it }}=\alpha+\beta_{1} L 1 . \operatorname{InCO} 2_{i t}+\beta_{2} \operatorname{InGDPPC}_{\text {it }}+\beta_{3} L 1 . \operatorname{InGDPPC} C_{\text {it }}
\end{aligned}
$$

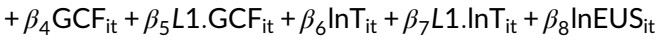

$$
\begin{aligned}
& +\beta_{9} L 1 . \operatorname{lnEUS} S_{i t}+\beta_{10} \mathrm{FDM}_{\mathrm{it}}+\sum_{j=1}^{m} \delta_{j} \mathrm{CFE}_{\mathrm{dum} j}+\sum_{j=1}^{n} \theta_{j} Y_{j}+\varepsilon_{\mathrm{it}}
\end{aligned}
$$

\section{3 | Estimation methods}

We estimate Equations (5) and (6) using both static and dynamic panel data estimators. As the static estimation methods, we use panel FGLS regression and regression with Prais-Winsten PCSEs estimators. The PCSE and FGLS static estimators can mitigate disturbances that are heteroscedastic, serially correlated, and contemporaneously correlated across panels, and also can be implemented on both balanced and unbalanced panel data (Greene, 2012). As the dynamic method, we use one-step Sys-GMM proposed by Arellano and Bover (1995) and Blundell and Bond (1998). In the GMM approach, the lagged values of the dependent variable are used as instruments in addition to other control variables to account for the endogeneity bias. We prefer Sys-GMM over first-differenced GMM since the firstdifferenced method is not efficient when the sample size is small (Levine, Loayza, \& Beck, 2000). In addition, Bond (2002) concluded that the first-differenced estimator may be biased if the data are not stationary, and higher accuracy of the estimation results can be achieved by using the Sys-GMM as the method uses a larger number of instruments and combines the regressions in the levels and in the first differences. Furthermore, the Sys-GMM is considered compara-

\begin{tabular}{|c|c|c|c|c|c|}
\hline Variable & Obs & Mean & $S D$ & Min & Max \\
\hline $\mathrm{LNCO}_{2}$ & 375 & $55,673.65$ & $104,858.80$ & 575.72 & $503,112.40$ \\
\hline LNEUS & 375 & 776.20 & 649.97 & 206.87 & $3,098.42$ \\
\hline $\mathrm{T}$ & 375 & $15,700.00$ & $23,400.00$ & 349.00 & $127,000.00$ \\
\hline FDM & 375 & 28.64 & 31.99 & 0.00 & 160.12 \\
\hline $\mathrm{InCO}_{2}$ & 375 & 9.52 & 1.69 & 6.36 & 13.13 \\
\hline Lneus & 375 & 6.41 & 0.64 & 5.33 & 8.04 \\
\hline Ingdppc & 375 & 6.56 & 1.89 & 0.46 & 9.28 \\
\hline Lnt & 375 & 22.54 & 1.43 & 19.67 & 25.57 \\
\hline
\end{tabular}
tively better since the instruments in the level equation are efficient

TABLE 3 Summary statistics

Note: Significance level: ${ }^{* * *} 1 \%,{ }^{* *} 5 \%$, and ${ }^{*} 10 \%$. Source: Authors' calculation. 
TABLE 4 Estimations on economic growth

\begin{tabular}{|c|c|c|c|}
\hline $\begin{array}{l}\text { Explanatory variables (Equation (5)) DEP VAR: } \\
\text { GDPPC }\end{array}$ & FGLS & PCSE & GMM \\
\hline L1GDPPC & $0.848^{* * *}(0.025)$ & $0.872^{* * *}(0.039)$ & $0.678^{* * *}(0.159)$ \\
\hline L1GCF & $0.005^{* * *}(0.001)$ & $0.006^{* * *}(0.002)$ & $0.013^{* *}(0.005)$ \\
\hline $\mathrm{LNCO}_{2}$ & $0.023(0.025)$ & $0.052(0.047)$ & $-0.181(0.131)$ \\
\hline L1LNEUS & $-0.093(0.058)$ & $-0.109(0.094)$ & $-0.052(0.203)$ \\
\hline FDM & $0.002^{* *}(0.001)$ & $0.002(0.001)$ & $0.003(0.002)$ \\
\hline L1FDM & $-0.003^{* * *}(0.001)$ & $-0.003^{* *}(0.001)$ & $0.002(0.005)$ \\
\hline LNT & $0.104^{* * *}(0.015)$ & $0.098^{* * *}(0.028)$ & $0.283^{* *}(0.114)$ \\
\hline No. countries & 15 & 15 & 15 \\
\hline No. observations & 360 & 360 & 360 \\
\hline $\operatorname{AR}(1)$ & - & - & $-2.41^{* *}$ \\
\hline $\operatorname{AR}(2)$ & - & - & -1.44 \\
\hline Sargan test & - & - & 9.95 \\
\hline Hansen test & - & - & 1.55 \\
\hline No. Instruments & - & - & 13 \\
\hline
\end{tabular}

Note: Significance level: ${ }^{* *} 1 \%$, ${ }^{* *} 5 \%$, and ${ }^{*} 10 \%$. Figures in parenthesis indicate HAC adjusted standard errors. Estimates for climate-zone fixed effects reported; however, for year fixed effects not reported.

predictors of the endogenous variables when the data time series follow a random walk process (Blundell \& Bond, 1998). Therefore, we consider the following generic specification of the Sys-GMM models:

$$
\begin{aligned}
\vartheta_{\mathrm{it}}= & \alpha_{i}+\gamma \vartheta_{\mathrm{i}, \mathrm{t}-1}+\sum_{p=1}^{p} \beta_{p} Z^{p}{ }_{\mathrm{it}}+\sum_{q=1}^{q} \beta_{q} Z^{q}{ }_{i \mathrm{t}}+\sum_{r=1}^{r} \beta_{\mathrm{r}} Z^{\mathrm{r}}{ }_{\mathrm{it}}+\sum_{j=1}^{m} \delta_{j} C F E_{\mathrm{dum} j} \\
& +\sum_{j=1}^{n} \theta_{j} Y_{j}+\varepsilon_{\mathrm{it}}
\end{aligned}
$$$$
\tau_{\text {it }}=\alpha_{i}+\gamma \tau_{i, t-1}+\sum_{p=1}^{p} \beta_{p} Z^{p}{ }_{i t}+\sum_{q=1}^{q} \beta_{q} Z^{q}{ }_{i t}+\sum_{r=1}^{r} \beta_{r} Z^{r}{ }_{i t}+\sum_{j=1}^{m} \delta_{j} \mathrm{CFE}_{\text {dum } j}
$$$$
+\sum_{j=1}^{n} \theta_{j} Y_{j}+\varepsilon_{i t} \text { and } \varepsilon_{i t}=v_{i t}+e_{i t}
$$

In the models above, $\vartheta_{\text {it }}$ and $\tau_{\text {it }}$ indicate GDPPC and $\mathrm{CO}_{2}$, respectively, of the $i$ African countries for $t$ years; $\alpha_{i}$ is the constant term, and $\gamma \vartheta_{i, t-1}$ represents the lag value of GDPPC, $Z_{i t}$ is the predictor variables and error-term is $\varepsilon_{\mathrm{it}}$. Like the static estimation, the SysGMM estimations also include the country fixed effects $\left(C_{\text {dum }}\right)$ to control for the effects of heterogonous unobserved factors across the countries and the time (year) fixed effects $\left(Y_{j}\right)$ to capture the time trend effects over the years considered. In addition, the unobserved growth specific factors and the idiosyncratic errors are $v_{i t}$ and $e_{i t}$, respectively. According to Blundell and Bond (1998) and Bond (2002), the model also takes the following assumptions:

$$
\begin{gathered}
\mathrm{E}\left(v_{\text {it }}, v_{\text {is }}\right)=0 \text { for } \mathrm{i}=1, \ldots . \mathrm{N} \text { and } \mathrm{t} \neq \mathrm{s} . \\
\text { and } \mathrm{E}\left(\vartheta_{\text {it }}, v_{\text {it }}\right)=0 \text { for } \mathrm{i}=1, \ldots . . \mathrm{N} \text { and } \mathrm{t}=2, \ldots . \mathrm{T} \text {. }
\end{gathered}
$$

\section{4 | Data}

Data with no missing values for the variables specified in this research are considered for 15 African counties covering the period from 1990 to 2014; Table A2 presents the list of the African countries selected. All data are collected from the World Development Indicators database of the World Bank.

Panel data are generally subject to autocorrelation, heteroscedasticity, and cross-sectional dependence problems, in addition to possible multicollinearity bias. Ignoring these issues can seriously compromise the statistical inferences. To account for all these issues in the base Equations (3) and (4), modified Wald for heteroscedasticity test, Wooldridge test for autocorrelation, variable inflation factor (VIF) test for multicollinearity, and Pesaran's (2004) 
TABLE 5 Estimation on $\mathrm{CO}_{2}$ emission

\begin{tabular}{|c|c|c|c|}
\hline Explanatory Variables (Equation (6)) DEP VAR: $\mathrm{CO}_{2}$ & FGLS & PCSE & GMM \\
\hline $\mathrm{L}_{1} \mathrm{LNCO}_{2}$ & $0.733^{* * *}(0.035)$ & $0.733^{* * *}(0.057)$ & $0.982^{* * *}(0.022)$ \\
\hline GDPPC & $0.074(0.061)$ & $0.074(0.065)$ & $0.023(0.085)$ \\
\hline GCF & $0.004^{*}(0.002)$ & $0.004(0.003)$ & $0.001(0.003)$ \\
\hline L1GCF & $-0.001(0.002)$ & $-0.001(0.003)$ & $-0.001(0.003)$ \\
\hline L1LNT & $-0.027(0.036)$ & $-0.027(0.037)$ & $-0.058^{* * *}(0.018)$ \\
\hline LNEUS & $0.187(0.122)$ & $0.187(0.148)$ & $0.101(0.192)$ \\
\hline L1LNEUS & $-0.136(0.113)$ & $-0.136(0.127)$ & $-0.108(0.197)$ \\
\hline FDM & $-(0.001)(0.001)$ & $-0.000(0.001)$ & $-0.000(0.000)$ \\
\hline Constant & $-0.423(0.616)$ & $-0.423(0.758)$ & $-0.132(0.308)$ \\
\hline No. observations & 360 & 360 & 360 \\
\hline $\operatorname{AR}(1)$ & - & - & $-2.22^{* *}$ \\
\hline $\operatorname{AR}(2)$ & - & - & -1.13 \\
\hline Sargan test & - & - & 0.11 \\
\hline Hansen test & - & - & 0.60 \\
\hline No. instruments & - & - & 12 \\
\hline
\end{tabular}

Note: Significance level: ${ }^{* * *} 1 \%,{ }^{* *} 5 \%$, and ${ }^{*} 10 \%$. Figures in parenthesis indicate HAC adjusted standard errors. Estimates for climate-zone fixed effects reported; however, for year fixed effects not reported.

cross-sectional dependence tests are implemented. Results for these diagnostic checks reported in Table A3 suggest that the data have significant levels of heteroscedasticity, autocorrelation, and cross-sectional dependence. The VIF stat and the correlation matrix in Tables A3 and A4 showing the general level of relationships among the variables also rules out the possibility of the existence of multicollinearity, following O'Brien (2007). Considering these results, the estimations of the equations are carried out with necessary adjustments.

\subsection{Data summary}

Table 3 reveals the average value of carbon emission to be $55,673.65$ metric tons per capita ( $\mathrm{mtpc}$ ) with Togo having the lowest average emission of 820.21 (mtpc) for the periods 1990-1994. The highest average, for the countries considered, was recorded by South Africa with 473,920.15 (mtpc) for the period 2010-2014. The SD of $104,858.80$ shows a huge deviation from the sample means. For energy consumption, Senegal recorded the lowest average EUS of $(216.16 \mathrm{~kg})$ for the period 1990-1994. South Africa recorded $(2,735 \mathrm{~kg})$ which was the highest average for the period 2005-2009. Also, a wide variation in energy used $(649.97 \mathrm{~kg})$ and per capita GDP (\$166.72) occur across the countries in the sample. Table 3 presents the descriptive statistics of all the variables, including their logarithm form.

\section{4 | RESULTS AND DISCUSSION}

Tables 4 and 5 present the FGLS, PCSE, and Sys-GMM) estimation results for Equations (5) and (6) with GDP per capita and $\mathrm{CO}_{2}$ emission as the dependent variables, respectively. The estimations utilize a total of 360 observations for the 15 countries included. All estimates include country fixed effects and time; however, their parameter estimates are not reported. The $R^{2}$ value from the PCSE estimation is .997 , suggesting a high explanatory power of the model specified. In the Sys-GMM estimation, the number of instruments is less than the number of countries, ensuring that the estimates are not weakened by too many instruments. As the variables of interest, the following discussion on the estimates focuses on $\mathrm{CO}_{2}$ emission and EUS first and then explains the other variables.

Results in Table 4 suggest that $\mathrm{CO}_{2}$ has no significant contemporaneous effect; however, a significant and negative effect at a oneperiod lag on GDP per capita. The significance of the impacts is consistently confirmed by both static and dynamic estimations. Results suggest that a $1 \%$ increase in $\mathrm{CO}_{2}$ emission reduce economic growth at a one-period lag by about $7.5,12.4$, and $19.6 \%$ according to the FGLS, PCSE, and Sys-GMM, respectively. A one period lag would mean increases in $\mathrm{CO}_{2}$ emission will reduce economic growth a year after for the African economies considered. These results are reasonable as $\mathrm{CO}_{2}$ emission is not expected to have instantaneous effects and could take time to have its effect reflected on the environment (e.g., pollution, warming, and diseases) which in turn lead to negative response from 
resources productivity and investment behavior of economic agents. The evidence on the negative impacts of $\mathrm{CO}_{2}$ emission on economic growth in the African economies is consistent with the previous literature (e. g., Akadiri, Bekun, Taheri, \& Akadiri, 2019; Al-Mulali \& Sab, 2012; Alshehry \& Belloumi, 2015; Bekun, Emir, \& Sarkodie, 2019; Ghosh, 2010; Kivyiro \& Arminen, 2014; Menyah \& Wolde-Rufael, 2010).

Results show that increases in EUS has a significant and positive effect on economic growth at a one period lag according to the SysGMM estimations. The result suggests a substantially large effect; a $1 \%$ increase in EUS reduces economic growth at a one-period lag by about $39.4 \%$. This result indicates the hefty role of energy availability and use as a key driver of economic growth of the African economies, as suggested by the past studies (e.g., Bayat, Tas, \& Tasar, 2017; Bekun \& Agboola, 2019; Fatai, 2014; Fotourehchi, 2017; Hasanov, Bulut, \& Suleymanov, 2017; Kahouli, 2018; Narayan, 2016).

Results further suggest GCF has a significant effect on economic growth; however, the effects appear to be negative at level but positive at a one period lag. While the one-period lag positive lag effects are consistently confirmed by both the static and dynamic estimators, the negative effect at level is suggested only by the static estimators. Results suggest that a $1 \%$ increase in capital formation increases economic growth by about $0.5,0.6$, and $1.3 \%$ according to the FGLS, PCSE, and Sys-GMM estimations, respectively. These results would indicate that increases in capital formulation in a certain year encourage economic growth in the following year for the African economies. This is plausible as increases in capital investment could take time to have impacts on production, employment, and markets. However, the results further suggest a concurrent negative effect in economic growth, which is possible when investments are not directed toward the necessary productive sectors rather dilutes markets and prices.

FDM appears to have a significant effect on economic growth, as suggested by the two static estimations. There is a sign of a positive concurrent effect; however, a negative one lag period effect. The differential effects of FDM on economic growth is evidenced by the past literature (e.g., Ahmed, 2017; Assefa \& Mollick, 2017; Ghirmay, 2004; Hassan, Sanchez, \& Yu, 2011; Kar, Nazlıoğlu, \& Ağır, 2011; Nyasha \& Odhiambo, 2017; Omri, Daly, Rault, \& Chaibi, 2015; Sassi \& Goaied, 2013; Uddin, Sjö, \& Shahbaz, 2013; Wang, Li, Abdou, \& Ntim, 2015).

Results further show that trade openness has a significant and positive effect on economic growth, consistently confirmed by all three estimators. A $1 \%$ increase in trade openness reduces economic growth by about $10.4,9.8$, and $28.3 \%$ according to the FGLS, PCSE, and Sys-GMM estimations, respectively. These results show the substantially influential role of trade in fostering economic growth for the African economies. International trade has been a key driver of economic growth for Africa, as evidenced by the previous literature (e.g., Gries, Kraft, \& Meierrieks, 2009; Menyah, Nazlioglu, \& WoldeRufael, 2014; Sakyi, 2011).

Findings from the results in Table 5 reveal that all the estimation techniques are in harmony. The result affirms that trade openness significantly increases $\mathrm{CO}_{2}$ emission contemporaneously in African countries. A $1 \%$ increase in trade openness could lead to an increase of
$\mathrm{CO}_{2}$ emission by $7.6-.7 \%$, as suggested by the different estimations produced. Results also show that other variables such as growth, and FDM have no significant effect on $\mathrm{CO}_{2}$ emission. Energy consumption adds to environmental degradation infinitesimally as confirmed by the three models. These results overall suggest the pivotal role of economic or trade openness in driving up pollution in the African nations; among the macroeconomic factors, it is trading activities that significantly increase emission in these countries. This goes to show that openness to trade in Africa adds to environmental deterioration. The continent's trade is at a cost to the environment. However, the components of the trade of the continents with the outside world, which is predominantly capital goods, are by no way helping the environment. Results further show limited significant and positive impact of GCF (our proxy for investment). A 1\% increase in GCF could lead to a $0.4 \%$ increase in $\mathrm{CO}_{2}$ emission, as suggested by FGLS estimation. The result confirms the potential contribution of capital investments in driving up pollution in the African nations.

\section{5 | CONCLUSION AND POLICY DIRECTIONS}

This study investigated the interrelationship between economic growth and $\mathrm{CO}_{2}$ emissions in Africa. The study relied on data spanning 1990-2014 and provided from both static and dynamic models. Our findings are in support of the energy-led growth hypothesis for Africa. We discovered that EUS adds to economic growth. Africa's energy mix is largely nonrenewable. Nonrenewable energy increases emissions thereby reducing environmental quality (BalsalobreLorente, Driha, Bekun, \& Osundina, 2019; Bekun, Emir, \& Sarkodie, 2019; Nathaniel, 2019; Nathaniel \& Iheonu, 2019). Therefore, for environmental sustainability, which is in line with the SDG 7 , there is a need for the adoption of renewable energy sources like tidal power, biogas, geothermal, solar, wave power, and so forth. These energy sources are actually low in emissions and can make growth sustainable. Some selected Africa countries have invested in these clean energy sources, but these investments have yielded very little or no impact at all on the environmental wellness in the continent. Just as Nathaniel and Iheonu (2019) have suggested, the institutions in Africa are weak, and needs strengthening. Strong institutions can curtail harmful trade, promote FDM, and improve economic growth. Since no country can survive in a vacuum, the need for trade is sacrosanct. However, since our findings have confirmed the horrendous effects of trade on the environment, the expansion of trade in the continent should be carried out with utmost diligence. A greater openness to trade can add to byproducts which will increase environmental pressure, cumulating to lower environmental quality. Perhaps, with the SDGs in sight, policymakers in these countries can do more in terms of adopting clean energy sources and strengthening of the already weak institutions. The continent should be involved in the importation of environmentally friendly technologies to aid production rather than concentrating on technological equipment that enhances emissions thereby encouraging environmental deterioration. 
Strong institutions can regulate imports, and clean energy sources can encourage energy efficiency. Policymakers should also concentrate on the development of the financial sector in Africa. This sector suffers from inadequate financing amid internal and external macroeconomic shocks. An efficient financial sector can enhance economic growth and make it sustainable.

\section{ORCID}

Solomon Nathaniel (D) https://orcid.org/0000-0001-7623-9526 Hamid Hussain (D) https://orcid.org/0000-0002-8519-7556

\section{REFERENCES}

Aboagye, S., \& Kwakwa, P. A. (2014). The relationship between economic growth and environmental sustainability: Evidence from selected SubSahara African countries. Ghanaian Journal of Economics, 2(1), 135-153.

Acemoglu, D., Johnson, S., \& Robinson, J. (2005). The rise of Europe: Atlantic trade, institutional change, and economic growth. American Economic Review, 95(3), 546-579.

Agboola, M. O., \& Bekun, F. V. (2019). Does agricultural value added induce environmental degradation? Empirical evidence from an agrarian country. Environmental Science and Pollution Research, 26(27), 27660-27676.

Ahmed, K. (2017). Revisiting the role of financial development for energygrowth-trade nexus in BRICS economies. Energy, 128, 487-495.

Akadiri, S. S., Bekun, F. V., Taheri, E., \& Akadiri, A. C. (2019). Carbon emissions, energy consumption and economic growth: A causality evidence. International Journal of Energy Technology and Policy, 15(2-3), 320-336.

Akalpler, E., \& Hove, S. (2019). Carbon emissions, energy use, real GDP per capita and trade matrix in the Indian economy-An ARDL approach. Energy, 168, 1081-1093.

Alam, M. J., Ahmed, M., \& Begum, I. A. (2017). Nexus between non-renewable energy demand and economic growth in Bangladesh: Application of maximum entropy bootstrap approach. Renewable and Sustainable Energy Reviews, 72, 399-406.

Alfaro, L., Chanda, A., Kalemli-Ozcan, S., \& Sayek, S. (2004). FDI and economic growth: The role of local financial markets. Journal of International Economics, 64(1), 89-112.

Al-Mulali, U., \& Sab, C. N. B. C. (2012). The impact of energy consumption and $\mathrm{CO} 2$ emission on the economic growth and financial development in the Sub Saharan African countries. Energy, 39(1), 180-186.

Alshehry, A. S., \& Belloumi, M. (2015). Energy consumption, carbon dioxide emissions and economic growth: The case of Saudi Arabia. renewable and Sustainable energy reviews, 41, 237-247.

Arellano, M., \& Bover, O. (1995). Another look at the instrumental variable estimation of error-components models. Journal of Econometrics, 68(1), 29-51.

Arestis, P., \& Baltar, C. T. (2019). A model of economic growth for an open emerging country: Empirical evidence for Brazil. Structural Change and Economic Dynamics, 49, 217-227.

Arifin, J., \& Syahruddin, N. (2011). Causality relationship between renewable and non-renewable energy consumption and GDP in Indonesia. Economics and Finance in Indonesia, 59(1), 1-18.

Asongu, S., El Montasser, G., \& Toumi, H. (2016). Testing the relationships between energy consumption, $\mathrm{CO} 2$ emissions, and economic growth in 24 African countries: A panel ARDL approach. Environmental Science and Pollution Research, 23(7), 6563-6573.

Assefa, T. A., \& Mollick, A. V. (2017). Financial development and economic growth in Africa. Journal of African Business, 18(3), 320-339.

Atici, C. (2009). Carbon emissions in Central and Eastern Europe: Environmental Kuznets curve and implications for sustainable development. Sustainable Development, 17(3), 155-160.
Aydın, C., \& Esen, Ö. (2017). Does too much energy consumption harm economic growth for Turkish republics in the transition process? New evidence on threshold effects. International Journal of Energy Economics and Policy, 7(2), 34-43.

Aydin, C., \& Esen, Ö. (2018). Does the level of energy intensity matter in the effect of energy consumption on the growth of transition economies? Evidence from dynamic panel threshold analysis. Energy Economics, 69, 185-195.

Aydin, N., Alrajhi, A. N., \& Jouini, J. H. (2018). Estimating the impact of R\&D spending on total factor productivity for OECD countries: Pooled mean group approach. The Journal of Developing Areas, 52(2), 159-168.

Azizalrahman, H. (2019). A model for urban sector drivers of carbon emissions. Sustainable Cities and Society, 44, 46-55.

Balcilar, M., Bekun, F. V., \& Uzuner, G. (2019). Revisiting the economic growth and electricity consumption nexus in Pakistan. Environmental Science and Pollution Research, 26(12), 12158-12170.

Balogh, J. M., \& Jámbor, A. (2017). Determinants of CO2 emission: A global evidence. International Journal of Energy Economics and Policy, 7 (5), 217-226.

Balsalobre-Lorente, D., Driha, O. M., Bekun, F. V., \& Osundina, O. A. (2019). Do agricultural activities induce carbon emissions? The BRICS experience. Environmental Science and Pollution Research, 26(24), 25218-25234.

Barro, R. J. (1991). Economic growth in a cross section of countries. The Quarterly Journal of Economics, 106(2), 407-443.

Barro, R. J. (2003). Determinants of economic growth in a panel of countries. Annals of Economics and Finance, 4, 231-274.

Barro, R. J., \& Lee, J. W. (1993). International comparisons of educational attainment. Journal of Monetary Economics, 32(3), 363-394.

Bayat, T., Tas, S., \& Tasar, I. (2017). Energy consumption is a determinant of economic growth in BRICS countries or not? Asian Economic and Financial Review, 7(8), 823-835.

Bekun, F. V., \& Agboola, M. O. (2019). Electricity consumption and economic growth nexus: Evidence from Maki cointegration. Engineering Economics, 30(1), 14-23.

Bekun, F. V., Alola, A. A., \& Sarkodie, S. A. (2019). Toward a sustainable environment: Nexus between $\mathrm{CO} 2$ emissions, resource rent, renewable and nonrenewable energy in 16-EU countries. Science of the Total Environment, 657, 1023-1029.

Bekun, F. V., Emir, F., \& Sarkodie, S. A. (2019). Another look at the relationship between energy consumption, carbon dioxide emissions, and economic growth in South Africa. Science of the Total Environment, 655, 759-765.

Bildirici, M. (2008). Political instability and growth: An econometric analysis of Turkey, Mexico, Argentina and Brazil. Applied Econometrics and International Development, 1985-2004.

Bildirici, M., \& Özaksoy, F. (2018). An analysis of biomass consumption and economic growth in transition countries. Economic ResearchEkonomska Istraživanja, 31(1), 386-405.

Bildirici, M. E. (2016). Biomass energy consumption and economic growth: ARDL analysis. Energy Sources, Part B: Economics, Planning, and Policy, 11(6), 562-568.

Birdsall, N., \& Rhee, C. (1993). Does results and development (R\&D) contribute to economic growth in developing countries? (No. 1221). The World Bank.

Bloom, D. E., Canning, D., \& Sevilla, J. (2004). The effect of health on economic growth: A production function approach. World Development, 32(1), 1-13.

Bloomberg, M., \& Pope, C. (2017). Climate of hope: How cities, businesses, and citizens can save the planet. St. Martin's Press.

Blundell, R., \& Bond, S. (1998). Initial conditions and moment restrictions in dynamic panel data models. Journal of Econometrics, 87(1), 115-143.

Bond, S. R. (2002). Dynamic panel data models: A guide to micro data methods and practice. Portuguese Economic Journal, 1(2), 141-162. 
Bong, C. P. C., Lim, L. Y., Ho, W. S., Lim, J. S., Klemeš, J. J., Towprayoon, S., ... Lee, C. T. (2017). A review on the global warming potential of cleaner composting and mitigation strategies. Journal of Cleaner Production, 146, 149-157.

BP, 2017. BP Statistical Review of World Energy 2017. Retrieved from http://www.bp.com/en/global/corperate/energy-economics/statisticalreview-of-world-energy/downloads.html.

Brizga, J., Feng, K., \& Hubacek, K. (2013). Drivers of CO2 emissions in the former Soviet Union: A country level IPAT analysis from 1990 to 2010. Energy, 59, 743-753.

Bruce, N., \& Turnovsky, S. J. (2013a). Social security, growth, and welfare in overlapping generations economies with or without annuities. Journal of Public Economics, 101, 12-24.

Bruce, N., \& Turnovsky, S. J. (2013b). Demography and growth: A unified treatment of overlapping generations. Macroeconomic Dynamics, 17(8), 1605-1637.

Bukhari, N., \& Waseem, M. (2017). Impact of energy consumption on CO2 emissions: Case of Pakistan. Journal of Management Info, 4(1), 1-5.

Burney, N. A., Mohaddes, K., Alawadhi, A., \& Al-Musallam, M. (2018). The dynamics and determinants of Kuwait's long-run economic growth. Economic Modelling, 71, 289-304.

Butkiewicz, J. L., \& Yanikkaya, H. (2006). Institutional quality and economic growth: Maintenance of the rule of law or democratic institutions, or both? Economic Modelling, 23(4), 648-661.

Cansino, J. M., Román, R., \& Ordonez, M. (2016). Main drivers of changes in $\mathrm{CO} 2$ emissions in the Spanish economy: A structural decomposition analysis. Energy Policy, 89, 150-159.

Carmona, M., Feria, J., Golpe, A. A., \& Iglesias, J. (2017). Energy consumption in the US reconsidered. Evidence across sources and economic sectors. Renewable and Sustainable Energy Reviews, 77, 1055-1068.

Cetin, M. A. (2016). Renewable energy consumption-economic growth nexus in E-7 countries. Energy Sources, Part B: Economics, Planning, and Policy, 11(12), 1180-1185.

Chin, M. Y., Puah, C. H., Teo, C. L., \& Joseph, J. (2018). The determinants of $\mathrm{CO} 2$ emissions in Malaysia: A new aspect. International Journal of Energy Economics and Policy, 8(1), 190-194.

Chong, A., \& Calderon, C. (2000). Causality and feedback between institutional measures and economic growth. Economics and Politics, 12(1), 69-81.

De Long, J. B., \& Summers, L. H. (1991). Equipment investment and economic growth. The Quarterly Journal of Economics, 106(2), 445-502.

Destek, M. A. (2017). Biomass energy consumption and economic growth: Evidence from top 10 biomass consumer countries. Energy Sources, Part B: Economics, Planning, and Policy, 12(10), 853-858.

Destek, M. A., \& Sarkodie, S. A. (2019). Investigation of environmental Kuznets curve for ecological footprint: The role of energy and financial development. Science of the Total Environment, 650, 2483-2489.

Dogan, E., \& Seker, F. (2016). Determinants of CO2 emissions in the European Union: The role of renewable and non-renewable energy. Renewable Energy, 94, 429-439.

Dogan, E., Seker, F., \& Bulbul, S. (2017). Investigating the impacts of energy consumption, real GDP, tourism and trade on $\mathrm{CO} 2$ emissions by accounting for cross-sectional dependence: A panel study of OECD countries. Current Issues in Tourism, 20(16), 1701-1719.

Dong, K., Jiang, H., Sun, R., \& Dong, X. (2019). Driving forces and mitigation potential of global CO2 emissions from 1980 through 2030: Evidence from countries with different income levels. Science of the Total Environment, 649, 335-343.

Dong, K., Sun, R., Li, H., \& Liao, H. (2018). Does natural gas consumption mitigate $\mathrm{CO} 2$ emissions: Testing the environmental Kuznets curve hypothesis for 14 Asia-Pacific countries. Renewable and Sustainable Energy Reviews, 94, 419-429.

Emir, F., \& Bekun, F. V. (2019). Energy intensity, carbon emissions, renewable energy, and economic growth nexus: New insights from Romania. Energy \& Environment, 30(3), 427-443.
Erdil Şahin, B. (2015). The Relationship between R\&D expenditures and economic growth: Panel data analysis 1990-2013 (No. 207). Ekonomik Yaklasim Association.

Ertugrul, H. M., Cetin, M., Seker, F., \& Dogan, E. (2016). The impact of trade openness on global carbon dioxide emissions: Evidence from the top ten emitters among developing countries. Ecological Indicators, 67, 543-555.

Esmail, H. A. H., \& Hemdan, R. K. (2018). Determinates of innovation and its relationship with economic growth in Saudi Arabia. The Business \& Management Review, 9(4), 223-229.

ESRL (Earth System Research Laboratory), NOAA. Trends in Atmospheric Carbon Dioxide. [online] Retrieved from https://www.esrl.noaa.gov/ gmd/ccgg/trends/weekly.html 2017.

Esso, L. J., \& Keho, Y. (2016). Energy consumption, economic growth and carbon emissions: Cointegration and causality evidence from selected African countries. Energy, 114, 492-497.

Fatai, B. O. (2014). Energy consumption and economic growth nexus: Panel co-integration and causality tests for Sub-Saharan Africa. Journal of Energy in Southern Africa, 25(4), 93-100.

Fotourehchi, Z. (2017). Clean energy consumption and economic growth: A case study for developing countries. International Journal of Energy Economics and Policy, 7(2), 61-64.

Fraj, S. H., Hamdaoui, M., \& Maktouf, S. (2018). Governance and economic growth: The role of the exchange rate regime. International Economics, 156, 326-364.

Galindo Martín, M. Á., Ribeiro, D., \& Mendez Picazo, M. T. (2012). Innovation and economic growth: Factors that encourages innovation. Cuadernos de Gestión, 12.

Gao, J., \& Zhang, L. (2014). Electricity consumption-economic growth$\mathrm{CO} 2$ emissions nexus in Sub-Saharan Africa: Evidence from panel cointegration. African Development Review, 26(2), 359-371.

Ghazali, A., \& Ali, G. (2019). Investigation of key contributors of CO2 emissions in extended STIRPAT model for newly industrialized countries: A dynamic common correlated estimator (DCCE) approach. Energy Reports, 5, 242-252.

Ghirmay, T. (2004). Financial development and economic growth in SubSaharan African countries: Evidence from time series analysis. African Development Review, 16(3), 415-432.

Ghosh, S. (2010). Examining carbon emissions economic growth nexus for India: A multivariate cointegration approach. Energy Policy, 38(6), 3008-3014.

Gozgor, G., Lau, C. K. M., \& Lu, Z. (2018). Energy consumption and economic growth: New evidence from the OECD countries. Energy, 153, 27-34.

Green, F., \& Stern, N. (2017). China's changing economy: Implications for its carbon dioxide emissions. Climate Policy, 17(4), 423-442.

Greene, W. H. (2012). Econometric analysis (7th ed.). Upper Saddle River $\mathrm{NJ}$ : Prentice Hall.

Gries, T., Kraft, M., \& Meierrieks, D. (2009). Linkages between financial deepening, trade openness, and economic development: Causality evidence from Sub-Saharan Africa. World Development, 37(12), 1849-1860.

Gwartney, J. D., Holcombe, R. G., \& Lawson, R. A. (2004). Economic freedom, institutional quality, and cross-country differences in income and growth. Cato Journal, 24, 205.

Hamilton, T. G. A., \& Kelly, S. (2017). Low carbon energy scenarios for sub-Saharan Africa: An input-output analysis on the effects of universal energy access and economic growth. Energy Policy, 105, 303-319.

Hansen, J., Satoa, M., Ruedy, R., Schmidtc, G. A., Lob, K., \& Persinb, A. (2017). Global Temperature in 2016.

Hasanov, F., Bulut, C., \& Suleymanov, E. (2017). Review of energy-growth nexus: A panel analysis for ten Eurasian oil exporting countries. Renewable and Sustainable Energy Reviews, 73, 369-386.

Hassan, M. K., Sanchez, B., \& Yu, J. S. (2011). Financial development and economic growth: New evidence from panel data. The Quarterly Review of Economics and Finance, 51(1), 88-104.

He, Q., \& Xu, B. (2019). Determinants of economic growth: A varyingcoefficient path identification approach. Journal of Business Research, $101,811-818$ 
Henderson, D. J., Papageorgiou, C., \& Parmeter, C. F. (2011). Growth empirics without parameters. The Economic Journal, 122(559), 125-154.

Hossain, M. S. (2011). Panel estimation for CO2 emissions, energy consumption, economic growth, trade openness and urbanization of newly industrialized countries. Energy Policy, 39(11), 6991-6999.

Ihnatov, I., \& Sprincean, N. (2015). Is CAPM an efficient model? Advanced versus emerging markets. EURINT, 2, 203-214.

Inekwe, J. N., Jin, Y., \& Valenzuela, M. R. (2019). Financial conditions and economic growth. International Review of Economics \& Finance, 61, 128-140.

Ito, K. (2017). CO2 emissions, renewable and non-renewable energy consumption, and economic growth: Evidence from panel data for developing countries. International Economics, 151, 1-6.

Ivanović, V., \& Stanišić, N. (2017). Monetary freedom and economic growth in new European Union member states. Economic ResearchEkonomska istraživanja, 30(1), 453-463.

Iwata, H., Okada, K., \& Samreth, S. (2012). Empirical study on the determinants of $\mathrm{CO} 2$ emissions: Evidence from OECD countries. Applied Economics, 44(27), 3513-3519.

Jamel, L., \& Derbali, A. (2016). Do energy consumption and economic growth lead to environmental degradation? Evidence from Asian economies. Cogent Economics \& Finance, 4(1), 1170653.

Ji, K., Magnus, J. R., \& Wang, W. (2014). Natural resources, institutional quality, and economic growth in China. Environmental and Resource Economics, 57(3), 323-343.

Kacprzyk, A., \& Doryń, W. (2017). Innovation and economic growth in old and new member states of the European Union. Economic ResearchEkonomska Istraživanja, 30(1), 1724-1742.

Kahia, M., Aïssa, M. S. B., \& Lanouar, C. (2017). Renewable and non-renewable energy use-economic growth nexus: The case of MENA net oil importing countries. Renewable and Sustainable Energy Reviews, 71, 127-140.

Kahouli, B. (2018). The causality link between energy electricity consumption, $\mathrm{CO} 2$ emissions, R\&D stocks and economic growth in Mediterranean countries (MCs). Energy, 145, 388-399.

Kais, S., \& Ben Mbarek, M. (2017). Dynamic relationship between CO2 emissions, energy consumption and economic growth in three North African countries. International Journal of Sustainable Energy, 36(9), 840-854.

Kar, M., Nazlıoğlu, Ş., \& Ağır, H. (2011). Financial development and economic growth nexus in the MENA countries: Bootstrap panel granger causality analysis. Economic Modelling, 28(1-2), 685-693.

Khan, A. Q., Saleem, N., \& Fatima, S. T. (2018). Financial development, income inequality, and $\mathrm{CO} 2$ emissions in Asian countries using STIRPAT model. Environmental Science and Pollution Research, 25(7), 6308-6319.

Kivyiro, P., \& Arminen, H. (2014). Carbon dioxide emissions, energy consumption, economic growth, and foreign direct investment: Causality analysis for Sub-Saharan Africa. Energy, 74, 595-606.

Klein, M. W. (2005). Capital account liberalization, institutional quality and economic growth: Theory and evidence (No. w11112). National Bureau of Economic Research.

Koengkan, M. (2018). The nexus between consumption of biofuels and economic growth: An empirical evidence from Brazil. Cadernos UniFOA, 12(35), 87-98.

Lau, L. S., Choong, C. K., \& Eng, Y. K. (2014). Investigation of the environmental Kuznets curve for carbon emissions in Malaysia: Do foreign direct investment and trade matter? Energy Policy, 68, 490-497.

Law, S. H., Azman-Saini, W. N. W., \& Ibrahim, M. H. (2013). Institutional quality thresholds and the finance-growth nexus. Journal of Banking \& Finance, 37(12), 5373-5381.

Le, T. H., Chang, Y., \& Park, D. (2016). Trade openness and environmental quality: International evidence. Energy Policy, 92, 45-55.

Lee, J. W., \& Hong, K. (2012). Economic growth in Asia: Determinants and prospects. Japan and the World Economy, 24(2), 101-113.

Lee, S. (2018). Growth, profits and R\&D investment. Economic ResearchEkonomska Istraživanja, 31(1), 607-625.
Leon-Gonzalez, R., \& Vinayagathasan, T. (2015). Robust determinants of growth in Asian developing economies: A Bayesian panel data model averaging approach. Journal of Asian Economics, 36, 34-46.

Levine, R., Loayza, N., \& Beck, T. (2000). Financial intermediation and growth: Causality and causes. Journal of Monetary Economics, 46(1), 31-77.

$\mathrm{Li}, \mathrm{K} .$, \& Lin, B. (2015). Impacts of urbanization and industrialization on energy consumption/CO2 emissions: Does the level of development matter? Renewable and Sustainable Energy Reviews, 52, 1107-1122.

Lin, S., Wang, S., Marinova, D., Zhao, D., \& Hong, J. (2017). Impacts of urbanization and real economic development on $\mathrm{CO} 2$ emissions in non-high income countries: Empirical research based on the extended STIRPAT model. Journal of Cleaner Production, 166, 952-966.

Liu, D., \& Xiao, B. (2018). Can China achieve its carbon emission peaking? A scenario analysis based on STIRPAT and system dynamics model. Ecological Indicators, 93, 647-657.

Liu, X., Zhang, S., \& Bae, J. (2018). Renewable energy, trade, and economic growth in the Asia-Pacific region. Energy Sources, Part B: Economics, Planning, and Policy, 13(2), 96-102.

Lv, Z., \& Xu, T. (2019). Trade openness, urbanization and CO2 emissions: Dynamic panel data analysis of middle-income countries. The Journal of International Trade \& Economic Development, 28(3), 317-330.

Ma, X., Wang, C., Dong, B., Gu, G., Chen, R., Li, Y., ... Li, Q. (2019). Carbon emissions from energy consumption in China: Its measurement and driving factors. Science of the Total Environment, 648, 1411-1420.

Mankiw, N. G., Romer, D., \& Weil, D. N. (1992). A contribution to the empirics of economic growth. The Quarterly Journal of Economics, 107 (2), 407-437.

Maria, H. A. (2010). Innovation-The cornerstone of economic success at European level. Annals of the University of Oradea, Economic Science Series, 19(2), 57-62.

Mariana, D. R. (2015). Education as a determinant of the economic growth. The case of Romania. Procedia-Social and Behavioral Sciences, 197, 404-412.

Menegaki, A. N., \& Ozturk, I. (2016). Renewable energy, rents and GDP growth in MENA countries. Energy Sources, Part B: Economics, Planning, and Policy, 11(9), 824-829.

Menyah, K., Nazlioglu, S., \& Wolde-Rufael, Y. (2014). Financial development, trade openness and economic growth in African countries: New insights from a panel causality approach. Economic Modelling, 37, 386-394.

Menyah, K., \& Wolde-Rufael, Y. (2010). Energy consumption, pollutant emissions and economic growth in South Africa. Energy Economics, 32 (6), 1374-1382.

Mierau, J. O., \& Turnovsky, S. J. (2014). Demography, growth, and inequality. Economic Theory, 55(1), 29-68.

Mirza, F. M., \& Kanwal, A. (2017). Energy consumption, carbon emissions and economic growth in Pakistan: Dynamic causality analysis. Renewable and Sustainable Energy Reviews, 72, 1233-1240.

Moutinho, V., Moreira, A. C., \& Silva, P. M. (2015). The driving forces of change in energy-related $\mathrm{CO} 2$ emissions in Eastern, Western, Northern and Southern Europe: The LMDI approach to decomposition analysis. Renewable and Sustainable Energy Reviews, 50, 1485-1499.

Mrabet, Z., \& Alsamara, M. (2017). Testing the Kuznets curve hypothesis for Qatar: A comparison between carbon dioxide and ecological footprint. Renewable and Sustainable Energy Reviews, 70, 1366-1375.

Narayan, S. (2016). Predictability within the energy consumption-economic growth nexus: Some evidence from income and regional groups. Economic Modelling, 54, 515-521.

Nasir, M., \& Rehman, F. U. (2011). Environmental Kuznets curve for carbon emissions in Pakistan: An empirical investigation. Energy Policy, 39(3), 1857-1864.

Nathaniel, S., Nwodo, O., Adediran, A., Sharma, G., Shah, M., \& Adeleye, N. (2019). Ecological footprint, urbanization, and energy consumption in South Africa: including the excluded. Environmental Science and Pollution Research, 26(26), 27168-27179. 
Nathaniel, S. P. (2019). Modelling urbanization, trade flow, economic growth and energy consumption with regards to the environment in Nigeria. GeoJournal, 1-15.

Nathaniel, S. P., \& Iheonu, C. I. (2019). Carbon dioxide abatement in Africa: The role of renewable and non-renewable energy consumption. Science of the Total Environment, 679, 337-345.

Nyasha, S., \& Odhiambo, N. M. (2017). Banks, stock market development and economic growth in Kenya: An empirical investigation. Journal of African Business, 18(1), 1-23.

O'Brien, R. M. (2007). A caution regarding rules of thumb for variance inflation factors. Quality \& Quantity, 41, 673-690.

Ohlan, R. (2016). Renewable and nonrenewable energy consumption and economic growth in India. Energy Sources, Part B: Economics, Planning, and Policy, 11(11), 1050-1054.

Omri, A., Daly, S., Rault, C., \& Chaibi, A. (2015). Financial development, environmental quality, trade and economic growth: What causes what in MENA countries. Energy Economics, 48, 242-252.

Omri, A., Nguyen, D. K., \& Rault, C. (2014). Causal interactions between CO2 emissions, FDI, and economic growth: Evidence from dynamic simultaneous-equation models. Economic Modelling, 42, 382-389.

Ozatac, N., Gokmenoglu, K. K., \& Taspinar, N. (2017). Testing the EKC hypothesis by considering trade openness, urbanization, and financial development: The case of Turkey. Environmental Science and Pollution Research, 24(20), 16690-16701.

Ozturk, I., \& Acaravci, A. (2010). CO2 emissions, energy consumption and economic growth in Turkey. Renewable and Sustainable Energy Reviews, 14(9), 3220-3225.

Pesaran, M. H. (2004). General diagnostic tests for cross section dependence in panels. Cambridge Working Papers in Economics, 0435, University of Cambridge.

Prašnikar, J., Redek, T., \& Drenkovska, M. (2017). Survival of the fittest: An evolutionary approach to an export-led model of growth. Economic Research-Ekonomska Istraživanja, 30(1), 184-206.

Radu, M. (2015). The impact of political determinants on economic growth in CEE countries. Procedia-Social and Behavioral Sciences, 197, 1990-1996.

Rafiq, S., Salim, R., \& Nielsen, I. (2016). Urbanization, openness, emissions, and energy intensity: A study of increasingly urbanized emerging economies. Energy Economics, 56, 20-28.

Raggad, B. (2018). Carbon dioxide emissions, economic growth, energy use, and urbanization in Saudi Arabia: Evidence from the ARDL approach and impulse saturation break tests. Environmental Science and Pollution Research, 25(15), 14882-14898.

Saboori, B., Sulaiman, J., \& Mohd, S. (2012). Economic growth and CO2 emissions in Malaysia: A cointegration analysis of the environmental Kuznets curve. Energy Policy, 51, 184-191.

Saidi, K., \& Hammami, S. (2015). The impact of CO2 emissions and economic growth on energy consumption in 58 countries. Energy Reports, 1, 62-70.

Saidi, K., \& Mbarek, M. B. (2017). The impact of income, trade, urbanization, and financial development on CO2 emissions in 19 emerging economies. Environmental Science and Pollution Research, 24(14), 12748-12757.

Sakyi, D. (2011). Trade openness, foreign aid and economic growth in post-liberalisation Ghana: An application of ARDL bounds test. Journal of Economics and International Finance, 3(3), 146-156.

Salahuddin, M., Alam, K., Ozturk, I., \& Sohag, K. (2018). The effects of electricity consumption, economic growth, financial development and foreign direct investment on $\mathrm{CO} 2$ emissions in Kuwait. Renewable and Sustainable Energy Reviews, 81, 2002-2010.

Sarkodie, S. A. (2018). The invisible hand and EKC hypothesis: What are the drivers of environmental degradation and pollution in Africa? Environmental Science and Pollution Research, 25(22), 21993-22022.

Sarkodie, S. A., \& Strezov, V. (2018). A review on environmental Kuznets curve hypothesis using bibliometric and meta-analysis. Science of the Total Environment, 649, 128-145.
Sarkodie, S. A., \& Strezov, V. (2019). Effect of foreign direct investments, economic development and energy consumption on greenhouse gas emissions in developing countries. Science of the Total Environment, 646, 862-871.

Sarkodie, S. A., Strezov, V., Weldekidan, H., Asamoah, E. F., Owusu, P. A., \& Doyi, I. N. Y. (2019). Environmental sustainability assessment using dynamic autoregressive-distributed lag simulationsNexus between greenhouse gas emissions, biomass energy, food and economic growth. Science of The Total Environment, 668, 318-332.

Sassi, S., \& Goaied, M. (2013). Financial development, ICT diffusion and economic growth: Lessons from MENA region. Telecommunications Policy, 37(4-5), 252-261.

Sbia, R., Shahbaz, M., \& Hamdi, H. (2014). A contribution of foreign direct investment, clean energy, trade openness, carbon emissions and economic growth to energy demand in UAE. Economic Modelling, 36, 191-197.

Sebri, M., \& Ben-Salha, O. (2014). On the causal dynamics between economic growth, renewable energy consumption, $\mathrm{CO} 2$ emissions and trade openness: Fresh evidence from BRICS countries. Renewable and Sustainable Energy Reviews, 39, 14-23.

Shahbaz, M., Nasreen, S., Ahmed, K., \& Hammoudeh, S. (2017). Trade openness-carbon emissions nexus: The importance of turning points of trade openness for country panels. Energy Economics, 61, 221-232.

Shahbaz, M., Zakaria, M., Shahzad, S. J. H., \& Mahalik, M. K. (2018). The energy consumption and economic growth nexus in top ten energyconsuming countries: Fresh evidence from using the quantile-on-quantile approach. Energy Economics, 71, 282-301.

Shahzad, S. J. H., Kumar, R. R., Zakaria, M., \& Hurr, M. (2017). Carbon emission, energy consumption, trade openness and financial development in Pakistan: A revisit. Renewable and Sustainable Energy Reviews, 70, 185-192.

Sharma, S. S. (2011). Determinants of carbon dioxide emissions: Empirical evidence from 69 countries. Applied Energy, 88(1), 376-382.

Shen, L., Wu, Y., Lou, Y., Zeng, D., Shuai, C., \& Song, X. (2018). What drives the carbon emission in the Chinese cities?-A case of pilot low carbon city of Beijing. Journal of Cleaner Production, 174, 343-354.

Shuai, C., Chen, X., Wu, Y., Zhang, Y., \& Tan, Y. (2019). A three-step strategy for decoupling economic growth from carbon emission: Empirical evidences from 133 countries. Science of the Total Environment, 646, 524-543.

Shuai, C., Shen, L., Jiao, L., Wu, Y., \& Tan, Y. (2017). Identifying key impact factors on carbon emission: Evidences from panel and time-series data of 125 countries from 1990 to 2011. Applied Energy, 187, 310-325.

Smaoui, H., \& Nechi, S. (2017). Does Sukuk market development spur economic growth? Research in International Business and Finance, 41, 136-147.

Sobel, R. S. (2008). Testing Baumol: Institutional quality and the productivity of entrepreneurship. Journal of Business Venturing, 23(6), 641-655.

Solarin, S. A., Al-Mulali, U., Musah, I., \& Ozturk, I. (2017). Investigating the pollution haven hypothesis in Ghana: An empirical investigation. Energy, 124, 706-719.

Tsaurai, K. (2017). Scaling up innovation: Does research and development have a role to play in economic growth? A case of Hungary. International Journal of Education Economics and Development, 8(1), 65-77.

Uddin, G. S., Sjö, B., \& Shahbaz, M. (2013). The causal nexus between financial development and economic growth in Kenya. Economic Modelling, 35, 701-707.

Ustabaş, A., \& Ersin, Ö. (2016). The effects of R\&D and high technology exports on economic growth: A comparative cointegration analysis for Turkey and South Korea. In International Conference on Eurasian Economies.

Valeriani, E., \& Peluso, S. (2011). The impact of institutional quality on economic growth and development: An empirical study. Journal of Knowledge Management, Economics and Information Technology, 1(6), 1-25.

Vedia-Jerez, D. H., \& Chasco, C. (2016). Long-run determinants of economic growth in South America. Journal of Applied Economics, 19(1), 169-192. 
Wang, J., \& Dong, K. (2019). What drives environmental degradation? Evidence from 14 Sub-Saharan African countries. Science of the Total Environment, 656, 165-173.

Wang, S., Wang, J., Li, S., Fang, C., \& Feng, K. (2019). Socioeconomic driving forces and scenario simulation of $\mathrm{CO} 2$ emissions for a fastdeveloping region in China. Journal of Cleaner Production, 216, 217-229.

Wang, Y., Li, X., Abdou, H., \& Ntim, C. G. (2015). Financial development and economic growth in China. Investment Management and Financial Innovations, 13(3), 8-18.

Well, D. N. (2007). Accounting for the effect of health on economic growth. The Quarterly Journal of Economics, 122(3), 1265-1306.

Weng, L., Song, W., \& Sheng, S. B. (2012). Empirical research on scientific and technical innovation and economic growth in Shanghai. American Journal of Operations Research, 2(01), 82-90.

World Bank. 2017. World Development Indicators. Retrieved from http:// databank.worldbank.org/data/reports.aspx?source=World\% 20Development\%20Indicators\#

Ye, B., \& Sun, X. (2010). Notice of Retraction Research of Economic Growth Based on Technical Innovation. In 2010 International Conference on E-Business and E-Government (pp. 5227-5230). IEEE.

Yeh, J. C., \& Liao, C. H. (2017). Impact of population and economic growth on carbon emissions in Taiwan using an analytic tool STIRPAT. Sustainable Environment Research, 27(1), 41-48.

Yew, S. L., \& Zhang, J. (2013). Socially optimal social security and education subsidization in a dynastic model with human capital externalities, fertility and endogenous growth. Journal of Economic Dynamics and Control, 37(1), 154-175.

Yülek, M. A. (2017). Why governments may opt for financial repression policies: Selective credits and endogenous growth. Economic ResearchEkonomska Istraživanja, 30(1), 1390-1405.

Zafar, M. W., Shahbaz, M., Hou, F., \& Sinha, A. (2019). From nonrenewable to renewable energy and its impact on economic growth: The role of research \& development expenditures in Asia-Pacific economic cooperation countries. Journal of Cleaner Production, 212, 1166-1178.

Zakarya, G. Y., Mostefa, B., Abbes, S. M., \& Seghir, G. M. (2015). Factors affecting $\mathrm{CO} 2$ emissions in the BRICS countries: A panel data analysis. Procedia Economics and Finance, 26, 114-125.

Zhang, C., \& Zhou, X. (2016). Does foreign direct investment lead to lower $\mathrm{CO} 2$ emissions? Evidence from a regional analysis in China. Renewable and Sustainable Energy Reviews, 58, 943-951.

Zhang, Y. X., Chao, Q. C., Zheng, Q. H., \& Huang, L. (2017). The withdrawal of the US from the Paris agreement and its impact on global climate change governance. Advances in Climate Change Research, 8(4), 213-219.

Zhao, W. (2016). Financial development and regional innovation output growth: Based on empirical analysis of provincial panel data in China. Modern Economy, 7(01), 10-19.

Zhou, Y., Fu, J., Kong, Y., \& Wu, R. (2018). How foreign direct investment influences carbon emissions, based on the empirical analysis of Chinese urban data. Sustainability, 10(7), 2163.

\section{AUTHOR BIOGRAPHIES}

Solomon Nathaniel is a PhD scholar (Advance Stage) at the University of Lagos, Akoka, Nigeria. He lectures economics at the Lagos State University, Badagry Campus, Nigeria. He has published in a variety of journals indexed in the web of science core collections such as Science of The Total Environment, Environmental Science and Pollution Research, Geojournal, Journal of
Public Affairs, Heliyon, Logforum, Serbian Journal of Management, Global Business Review, etc.

Suborna Barua, PhD is Assistant Professor at the Department of International Business, University of Dhaka. He holds a blended experience of teaching both postgraduate and undergraduate level courses in economics and finance at both local and foreign universities, delivering professional training on financial modelling, financial markets, financial management and project management, and working as a research team member in multinational academic and professional research projects funded by institutions like the World Bank, UNDP, DFID, and Plan Bangladesh. Furthermore, he has served in financial and management consultant and advisory roles at overten local and multinational corporations. Suborna's research interest is in the interactions between trade, finance, environment, and climate change, and the applications of machine learning in finance and economics. His publication portfolio includes book chapters and over twenty-five articles published in internationally ranked, high-impact factor journals, and he has attended and presented at more than twelve international conferences. Suborna holds a Doctor of Philosophy $(\mathrm{PhD})$ in Finance and Economics from Federation University Australia and BBA and MBA in Finance from the University of Dhaka, Bangladesh.

Hamid Hussain is a PhD candidate at the Department of Economics, Institute of Business Administration, Karachi. His research focuses on poverty, economic development, tourism economics and financial economics.

Ngozi Adeleye $(\mathrm{PhD})$ is a researcher and lecturer in the Department of Economics and Development Studies, Covenant University, Nigeria and a Research Fellow at the Centre for Economic Policy and Development Research (CEPDeR). She is quantitative-inclined with proficiency in Stata, EViews and SPSS analytical software. She is the Tutor and Creator of CrunchEconometrix https://www.youtube. com/c/CrunchEconometrix a digital platform dedicated to teaching hands-on applied econometrics to beginners and intermediate-level researchers. Her digital platform has become a succour for students and researchers across the globe. Her research interests revolve on issues related to Sustainable Development Goals (SDGs) such as income inequality, institutions, energy, financial, monetary, industrial and agricultural economics with some of her works presented in local and international Conferences. A reviewer to some international journals.

How to cite this article: Nathaniel S, Barua S, Hussain $\mathrm{H}$, Adeleye $\mathrm{N}$. The determinants and interrelationship of carbon emissions and economic growth in African economies: Fresh insights from static and dynamic models. J Public Affairs. 2020; e2141. https://doi.org/10.1002/pa.2141 


\section{APPENDIX}

TABLE A1 Definition of the variables used

\begin{tabular}{|c|c|c|}
\hline Notation & Variable name & Definition \\
\hline GDPPC & $\begin{array}{l}\text { GDP per capita (in } \\
\text { constant } \$ 2010 \text { ) }\end{array}$ & $\begin{array}{l}\text { This is the ratio of GDP to } \\
\text { the total population }\end{array}$ \\
\hline $\mathrm{CO}_{2}$ & $\begin{array}{l}\mathrm{CO}_{2} \text { emission in kilo } \\
\text { ton (kt) }\end{array}$ & $\begin{array}{l}\text { EUS refers to use of primary } \\
\text { energy before } \\
\text { transformation to other } \\
\text { end-use fuels, which is } \\
\text { equal to indigenous } \\
\text { production plus imports } \\
\text { and stock changes, minus } \\
\text { exports and fuels supplied } \\
\text { to ships and aircraft } \\
\text { engaged in international } \\
\text { transport }\end{array}$ \\
\hline GCF & GCF as $\%$ of GDP & $\begin{array}{l}\text { Annual gross capital } \\
\text { formation based on } \\
\text { constant } \$ 2010 \text {. GCF } \\
\text { consists of outlays on } \\
\text { additions to the fixed } \\
\text { assets of the economy plus } \\
\text { net changes in the level of } \\
\text { inventories }\end{array}$ \\
\hline $\mathrm{T}$ & Trade (\% of GDP) & $\begin{array}{l}\text { The sum of import and export } \\
\text { measured as a share of } \\
\text { GDP }\end{array}$ \\
\hline EUS & $\begin{array}{l}\text { in } \mathrm{kg} \text { of oil equivalent } \\
\text { per capita }\end{array}$ & $\begin{array}{l}\text { It encompasses primary } \\
\text { energy before } \\
\text { transformation to other } \\
\text { end-use fuel }\end{array}$ \\
\hline FDM & Financial development & $\begin{array}{l}\text { Financial sector development } \\
\text { is a set of institutions and } \\
\text { markets in addition to a } \\
\text { regulatory and legal } \\
\text { framework that allows } \\
\text { transactions to be made by } \\
\text { given credit, particularly to } \\
\text { the private sector }\end{array}$ \\
\hline
\end{tabular}

Note: Source: Author compiled.
TABLE A2 List of countries considered in the research

\begin{tabular}{ll}
\hline Algeria & Morocco \\
\hline Cameroon & Nigeria \\
\hline Congo rep & Senegal \\
\hline Egypt & South Africa \\
\hline Ethiopia & Sudan \\
\hline Gabon & Togo \\
\hline Ghana & Tunisia \\
\hline Kenya & \\
\hline
\end{tabular}

Note: Source: Author compiled. 
TAB LE A3 Diagnostic checks for Equations (3) and (4)

\begin{tabular}{|c|c|c|c|c|}
\hline $\begin{array}{l}\text { Tests and reported } \\
\text { statistics }\end{array}$ & $\begin{array}{l}\text { Heteroscedasticity } \\
\text { Modified Wald test } \chi^{2} \\
\text { statistic) }\end{array}$ & $\begin{array}{l}\text { Autocorrelation } \\
\text { Wooldridge test ( } F \\
\text { statistic) }\end{array}$ & $\begin{array}{l}\begin{array}{l}\text { Cross-sectional } \\
\text { dependence }\end{array} \\
\text { Pesaran (2004) CD test }\end{array}$ & $\begin{array}{l}\text { Multicollinearity } \\
\text { VIF test } \\
\text { (mean VIF) }\end{array}$ \\
\hline Equation (5) & $703.02^{* * *}$ & $81.241^{* * *}$ & $-2.894^{* * *}$ & 1.55 \\
\hline Equation (6) & $1831.28^{* * *}$ & $58.919^{* * *}$ & -1.249 & 1.49 \\
\hline
\end{tabular}

Note: Significance level: ${ }^{* * *} 1 \%,{ }^{* *} 5 \%$, and ${ }^{*} 10 \%$.

Note: Source: Author compiled.

TABLE A4 Correlation matrix

\begin{tabular}{|c|c|c|c|c|c|c|}
\hline & $\operatorname{lnCO} C_{2}$ & InEUS & InGDPPC & $\ln T$ & FDM & InGCF \\
\hline $\mathrm{InCO}_{2}$ & 1.000 & & & & & \\
\hline InEUS & 0.584 & 1.000 & & & & \\
\hline $\ln T$ & 0.873 & 0.559 & 0.139 & 1.000 & & \\
\hline FDM & 0.627 & 0.521 & 0.171 & 0.521 & 1.000 & \\
\hline
\end{tabular}

Note: Source: Author compiled. 